\title{
PALABRAS POR MIGUEL MONTES GARCÍA EN EL RECONOCIMIENTO AL MAESTRO EUGENIO TRUEBA OLIVARES, POR SU OBRA JURÍDICA 16 DE FEBRERO DE 2015
}

Agradezco y correspondo a la invitación que la doctora Teresita Rendón me hizo para asistir a este acto, que tiene como fin el reconocimiento a la obra jurídica del Maestro don Eugenio Trueba Olivares.

Me enfrento al cumplimiento de un encargo difícil; mi cercanía con don Eugenio me permite conocer que le incomodan los elogios y en múltiples ocasiones, pública y privadamente, lo ha manifestado; él se ha esforzado siempre por mantener su modestia imperturbada, pero nadie puede negar la valía de su obra jurídica y su ejemplaridad en el ejercicio de la profesión de abogado.

En el libro que editó la Quincuagésima Octava Legislatura del Congreso del Estado, también como reconocimiento al Maestro Trueba, afirmé, y ahora lo reitero, que: "Eugenio Trueba Olivares es abogado y, como tal, no solo ha ejercido la profesión postulando en su despacho, sino que ha sido maestro, juez, asesor de diversos funcionarios públicos, él mismo ha sido servidor público, Rector de la Universidad de Guanajuato en dos ocasiones, Presidente del Supremo Tribunal de Justicia y siempre, siempre, consejero de buena fe de todos los que han acudido a él solicitando su orientación: familiares, alumnos, amigos, abogados y clientes".

"Su calidad de abogado ha matizado toda su obra: la de maestro, la de director teatral, la de ensayista, la de cuentista, la de novelista, en fin, la de escritor, porque todos estos géneros ha cultivado e, insisto, su vocación por el Derecho se muestra en cada una de sus acciones".

"Su vocación jurídica está reforzada por una lúcida conciencia ética, no encuentra y no hay contradicciones entre lo moral y lo jurídico”.

En el mismo libro editado por la Quincuagésima Octava Legislatura local, otro destacado y esforzado abogado, investigador y maestro de nuestra Universidad, mi compañero el licenciado Diego León y Rábago, hizo un estudio muy amplio y sólido, de la obra de don Eugenio; sostiene que del pensamiento del Maestro Trueba, expuesto en libros, tales como Derecho y Persona Humana; El Hombre, la Moral y el Derecho; El Agravio en la Ley; El Pensamiento de Vitoria y otros, se desprenden varias tesis jurídicas fundamentales que, afirma, son de raíces principalmente tomistas, lo que sitúa al homenajeado dentro de la corriente neo tomista que surgió en el siglo XX y se desarrolló aceleradamente después de la desaparición de las grandes dictaduras y del neo socialismo alemán, en franca oposición las posturas positivistas y formalistas jurídicas y al materialismo marxista y, agrega, que "el principal mérito del autor, aparte de sus acertadas críticas a tales sucesos históricos y direcciones del pensamiento..., es 
el de integrar un sistema de pensamiento coherente y lógico, difícilmente vulnerable", señala Diego que el doctor Trueba propone las siguientes tesis, que resumo:

Primera.- "La afirmación de que para el estudio del Derecho es indispensable conocer las cualidades definitorias del hombre, pues es éste el protagonista del Derecho".

Segunda.- “... solo hay una esfera normativa y la consecuente negación de la neutralidad ética del Derecho, principal postulado del positivismo jurídico”.

Tercera.- “... la existencia del Derecho mediante la afirmación de que su origen no puede consistir en otra cosa que no sea la necesidad de cumplir exigencias morales de convivencia. En este sentido el Derecho es una especie de sucedáneo de la moral social para suprimir o contrarrestar el estado de guerra, introduciendo un mínimo de orden para la conservación de la paz".

Cuarta.- "Con todo lo anterior el tratadista rechaza las principales propuestas y soluciones positivistas y formalistas, sin que por ello deje de reconocer sus escasos aciertos. En algunas ocasiones le escuchamos decir que el positivismo y el formalismo habían sido movimientos del pensamiento jurídico necesarios para someter a revisión y corrección los conceptos iusnaturalistas que habían caído en desprestigio por incurrir en desviaciones racionalistas individualistas. También lo escuchamos referir comentarios favorables a algunas aportaciones, como el análisis kelseniano de la estructura lógica de la norma" y sintetiza: “... el autor insiste en el postulado de que la obligatoriedad de los preceptos jurídicos no puede fundarse más que en su propio contenido de valor”.

Quinta.- Sostiene el licenciado León y Rábago que el doctor Trueba no apoya todo postulado iusnaturalista incondicionalmente, sino que, en diversos lugares de su obra, reconoce también los aciertos de las teorías formalistas y positivistas y se podrá aceptar que existen instancias permanentes, principios jurídicos fundamentales, no accidentales ni históricos, que explican, aprueban o condenan la ley positiva, no hay una dicotomía que coloque "al Derecho Natural como algo distinto y hasta antagónico del Derecho Positivo": para Trueba, repite, "hay un orden normativo único por lo que no puede haber neutralidad ética del Derecho. Toda norma, sea jurídica o moral, persigue siempre el fin de perfeccionamiento humano por lo cual no puede haber diferenciación esencial entre la Moral y el Derecho".

"Por todo ello el doctor Trueba Olivares se sitúa dentro de la corriente de la resurrección moderna del Derecho Natural, como la denomina Edgar Bodenheimer, o del retorno del Derecho Natural, como la llama Enrique Rommen”. Fin de la cita.

La doctrina jurídica que sostiene el Maestro Trueba es consistente, congruente con su acción, pues don Eugenio no se quedó solo inmerso en la teoría, sino que en su quehacer cotidiano, se ha esforzado por llevar a la práctica sus tesis doctrinarias y mejorar la realidad en que vivimos. No ocurre con don Eugenio lo que otro gran jurista mexicano, don Felipe Tena Ramírez, señaló con cortés suavidad, en una de sus magistrales conferencias: la contradicción que tienen algunos abogados postulantes que en su práctica niegan lo que sostienen en sus libros y en sus cátedras, lo que hace parecer que se trata de dos personas diferentes, por el contrario, existe una gran identidad entre el pensamiento teórico que sostiene don Eugenio y su actuar profesional. De él aprendimos que la abogacía es esencialmente una consejería 
social, que empieza por analizar si el cliente tiene la razón legal y conlleva el deber de informarle el parecer del jurista y los riesgos que siempre existen, en mayor o menor medida, en todos los litigios. Si un postulante procura siempre defender a quien, desde su punto de vista, es asistido por la razón de la ley, no solo se aumenta considerablemente la posibilidad de triunfar en un litigio, sino que también se traduce en mayor prestigio del abogado. Esto no significa que no merezca orientación la persona a quien no respalda la norma, vale y se debe sacarlo de su error, de su ignorancia o de su mala fe y conviene defenderlo para buscar un arreglo conciliatorio, justo, entre las partes en conflicto. Solamente así se cumple la obligación ética permanente del jurisconsulto: resolver los conflictos de la mejor forma que existe, tal vez la más equitativa y la más eficaz, la conciliación, vía que don Eugenio defiende en su libro El Agravio en la Ley y se estableció en la Ley de Justicia Alternativa del Estado de Guanajuato, de la que fue corredactor.

Nos enseñó a no ensoberbecernos de los supuestos conocimientos y habilidades jurídicoprocesales y a no encarecer desmedidamente la prestación del servicio profesional, pues son la sociedad y la vida en comunidad y el estado organizado para impartir justicia, los que dan valor al trabajo abogadil. ¡Qué inútil hubiese sido para Robinson Crusoe en su isla desierta ser abogado!

El licenciado Trueba, insisto, no se ha quedado en la prédica, siempre ha pasado a la acción: notó que hacía falta la orientación ética a los alumnos de la Facultad de Derecho y a muchos abogados e influyó, destacadamente, para que se creasen las clases de Ética Profesional y la de Hermenéutica Jurídica, de las que fue titular y evitó que el programa de estudios de la Ética fuese solo, vicio frecuente, una historia de las doctrinas éticas; se preocupó por enseñar que la ética más que aprenderse se vive, que lo importante y trascendente es descubrir y realizar el valor de lo bueno; con sencillez y claridad estableció, en puntos concretos, qué debe hacer un abogado en los casos que se le presentan para salvar la eticidad e incluye en su Ética Profesional para el Ejercicio del Derecho, capítulos que desde su nombre y sus subtítulos reflejan las preocupaciones profundas del autor e indican los caminos sencillos para evitar desvíos éticos a todos quienes trabajan en la creación, la interpretación y la aplicación de las normas jurídicas; su libro es de una practicidad clara y sencilla que invita a cumplir el deber y enseña cómo hacerlo.

Don Eugenio Trueba Olivares como abogado postulante, ha defendido con pasión el cumplimiento del Derecho para lograr la realización de los valores que le son substanciales: la seguridad y la justicia, pero insistiendo en que se complementan y que una seguridad para cumplir una ley injusta no sirve a la sociedad y la justicia sin certeza produce incertidumbre perniciosa. Algunas anécdotas que he compartido con él, hacen patente su vigor en la defensa de la justicia:

Hubo una vez que reclamó la negativa de la protección constitucional a un trabajador burocrático que la merecía, por la excesiva condescendencia que, a su juicio, tuvo la autoridad federal con el gobierno del estado, no existía entonces la ley regulatoria de las relaciones laborales entre los trabajadores estatales y municipales con sus patrones y la única vía para su defensa era el juicio de amparo, el perjuicio para el trabajador, cuando se negaba el amparo, era irreparable; ante esa circunstancia el licenciado Trueba que tenía cercanía con la autoridad resolutora, le reclamó y, ante el reclamo, la resolutora le contestó que no tenía derecho a excederse en sus palabras. El Maestro Trueba reconoció su exceso y presentó la siguiente 
jurídica excusa: "tienes razón, sigo pensando que te faltó valentía para hacer justicia, pero eso no me da derecho a decírtelo, interpondré la revisión".

Recuerdo también otro asunto en que un hijo demandó a sus padres, que poco a poco, con trabajo esforzado y desde muy jóvenes habían acumulado un número considerable de bienes inmuebles y habían puesto varios de ellos a nombre de sus diversos hijos para que, cuando ellos, los padres, fallecieran, los hijos ya fuesen propietarios de esos bienes. En la demanda se reclamaba a los padres no solo la entrega de los bienes al hijo, ya mayor de edad en esos momentos, sino la rendición de cuentas de la administración que los padres habían realizado durante muchos años, más de quince posteriores a la mayoría de edad del actor, colitigamos el asunto y se probó que los padres, mediante la prescripción adquisitiva del derecho real, eran los titulares del usufructo vitalicio, por el tiempo transcurrido posterior a la mayoría de edad del hijo demandante y, en consecuencia, se les absolvió de rendir cuentas de la administración y de devolver los bienes mientras viviesen y se reconoció la nuda propiedad a favor del hijo. Nuestros clientes se beneficiaron con varios millones de aquellos pesos, continuaron disfrutando los inmuebles y nosotros cobramos los honorarios pactados que, según recuerdo, fueron setenta y cinco mil pesos, eso sí, en cómodos pagos mensuales de tres mil pesos.

Para don Eugenio los honorarios cuantiosos nunca han sido la causa eficiente de su ejercicio profesional.

Narraré dos casos más: un abogado notable, ex-alumno del Maestro Trueba, le pidió opinión sobre un caso complicado que llevaba; en una servilleta en el café "Valadez", donde se encontraban, manuscribió sintéticamente lo que debía hacerse, precisando los pasos procesales a seguir. Creo que el asunto lo ganó el consultante que aceptó la recomendación y a cuyo cargo estuvo, desde luego, el pago del costo del café.

En otra ocasión, el licenciado Hilarión Espinosa Ayala y yo, que compartíamos el despacho con él, acordamos, para poder cobrar nosotros lo que creíamos conveniente, solicitarle elevase sus emolumentos y argumentamos que si él, con su trayectoria y su prestigio, cobraba tan poquito, nosotros tendríamos que solicitar menos, lo que no nos permitiría mantener el despacho; se convenció de nuestras razones y ofreció cobrar adecuadamente e, incluso, preguntarnos el monto. A los pocos días una señora, por cierto de nacionalidad estadounidense, lo visitó para hacerle una consulta, el doctor Trueba la atendió, desahogó la consulta, la orientó y la señora le dio las gracias y se fue; en ese momento el Maestro Trueba se acordó de lo que habíamos conversado, salió de su privado y en voz alta le dijo a la dama: "señora no le he cobrado", ella contestó: “tiene razón licenciado, ¿cuánto le debo?”; él con voz clara le contestó: "son veinte pesos".

Han sido múltiples y variados los temas jurídicos que el doctor Trueba ha abordado con un enfoque crítico-constructivo, lo ha hecho en artículos, ensayos, libros y clases. No está de acuerdo con el exceso de leyes que crean una impenetrable maraña jurídica y coadyuvó en la hechura de la Primera Compilación de Leyes del Estado de Guanajuato, editada por la Quincuagésima Primera Legislatura local, a fin de averiguar con certeza cuáles eran las vigentes e innecesarias para, en un limpio trabajo legislativo, abrogarlas.

Está convencido que el centralismo exagerado subsiste en México y lo conveniente es disminuirlo, para ello, hace años, presentó ante el Pleno de la Academia Mexicana del Derecho del Trabajo, en su carácter de miembro numerario, la proposición de que se creasen las juntas regionales de conciliación y arbitraje, moderando los viajes obligados a la ciudad de México de trabajadores y abogados, pues allí radicaba la única junta de conciliación y 
arbitraje del País. Esta propuesta se aprobó y fue antecedente de la actual organización de las juntas de conciliación y arbitraje, por cierto, ya insuficientes. Por la misma razón y para evitar el abuso del juicio de amparo, como Presidente del Supremo Tribunal de Justicia, en una asamblea nacional de los presidentes de tribunales de justicia mexicanos, propuso la desaparición del llamado amparo de casación, sostiene, con razón, que el juicio de amparo no nació para combatir resoluciones judiciales, sino como defensa contra los actos inconstitucionales de las autoridades distintas a la judicial; le parece que el amparo casación impone a los jueces locales una capitis diminusio que contradice al federalismo jurídico y lo sujeta a un control central exagerado.

Sabe que las leyes largas y farragosas no ayudan a la impartición de justicia y desea pocas leyes, claras, sencillas, sin casuismos inútiles y confundidores. Sostiene que la ley, por sí misma, no resuelve ningún problema, es su aplicación la que los atenúa, por lo que importa más un buen juez que una buena ley.

No quiere la excesiva penalidad para ningún delito porque lo importante no es aumentar la pena sino abatir la impunidad.

Está convencido que los procedimientos complejos y largos impulsan las trampas procesales, alargan los juicios y fomentan el criterio erróneo de que los mejores abogados son los que conocen y crean más intrincados vericuetos procedimentales. Ha procurado y procura la sentencia pronta porque una solución tardía daña a todos; la justicia diferida no es justicia.

Quiere el cumplimiento del principio jurídico de que a los jueces se les den los hechos y ellos aporten el Derecho y no se opone a aumentar las facultades investigatorias del juez, no solo en los casos para mejor proveer que, por desgracia, raras veces se ejercitan, sino siempre.

En nuestros desayunos de los viernes soñamos con un procedimiento único en que el juez, receptor de los hechos, indicase a las partes, con la mejor buena fe, las pruebas que cada una de ellas debe aportar para demostrar los hechos en que funda su pedimento. No considera desechable, a priori, la universal suplencia de la queja porque el defecto de la petición no supone la injusticia de la causa. No saber pedir no es sinónimo de no tener razón.

Asevera que conviene utilizar en todos los procedimientos jurídicos los modernos medios tecnológicos que guarden sus testimonios, siempre y cuando faciliten y abrevien el tiempo para dictar las sentencias y no encarezcan excesivamente el costo del cumplimiento de la obligación estatal de salvaguardar el Derecho.

Maestro Trueba:

En una entrevista que le hizo don José Argueta Acevedo, le preguntó: “¿Existe el "truebismo"?" y usted contestó textualmente: "No, no existe. Esos cuentos de algún periodista. A veces se me señala como interventor de algunos acontecimientos y yo soy el primero en sorprenderme de que ande metido allí. Pero con toda sinceridad le digo que no he creado ninguna capilla, ningún grupo, ni ninguna mafia. Tengo buenos amigos, en todas partes, pero hasta alli". Respondió usted la verdad, pues la pregunta se refería al "truebismo" político-partidario o electorero y en ese sentido como grupo nunca ha existido, pero la respuesta creo que no vale si se aplica a otros aspectos, pues existe el "truebismo", por lo menos en Guanajuato, como corriente de pensamiento jurídico, como corriente de preocupación social, como corriente cultural en el teatro y como ejemplo de buen servicio a la Universidad, a la comunidad guanajuatense, en la ciudad de Guanajuato y en el Estado. A esta corriente que, afectuosamente y con respeto, quiero llamar "truebismo", pertenecemos muchos aboga- 
dos de Guanajuato, no solo sus alumnos de cátedra sino también quienes han leído sus libros y escuchado sus conferencias y pláticas sobre el Derecho.

He procurado no pronunciar ningún halago ni exagerar, por el afecto que le tengo, sus virtudes. Si algún elogio dije, ruego su comprensión, después de todo se trata de un acto de reconocimiento que usted merece ampliamente. Sin faltar a la verdad, sin exageración alguna termino reiterando que el Maestro don Eugenio Trueba Olivares es un auténtico valor del mejor Guanajuato. 